This document was prepared in conjunction with work accomplished under Contract No. DE-AC09-96SR18500 with the U. S. Department of Energy.

\title{
DISCLAIMER
}

This report was prepared as an account of work sponsored by an agency of the United States Government. Neither the United States Government nor any agency thereof, nor any of their employees, nor any of their contractors, subcontractors or their employees, makes any warranty, express or implied, or assumes any legal liability or responsibility for the accuracy, completeness, or any third party's use or the results of such use of any information, apparatus, product, or process disclosed, or represents that its use would not infringe privately owned rights. Reference herein to any specific commercial product, process, or service by trade name, trademark, manufacturer, or otherwise, does not necessarily constitute or imply its endorsement, recommendation, or favoring by the United States Government or any agency thereof or its contractors or subcontractors. The views and opinions of authors expressed herein do not necessarily state or reflect those of the United States Government or any agency thereof. 
WSRC-TR-2005-00369 (U)

\section{F-area Type IV Tank Liner Life Estimation (U)}

\section{B. J. Wiersma}

Savannah River National Laboratory

Materials Science and Technology
DOES NOT CONTAIN

UNCLASSIFIED CONTROLLED

NUCLEAR INFORMATION

ADC \&

Reviewing

Official:S.L. West/L.L, Whet

Date:

Publication Date: October, 2005

\section{Westinghouse Savannah River Company Savannah River Site Aiken, SC 29808}

This document was prepared in connection with work done under Contract No. DE-AC09-96SR18500 with the U. S. Department of Energy 


\section{DISCLAIMER}

This report was prepared as an account of work sponsored by an agency of the United States Government. Neither the United States Government nor any agency thereof, nor any of their employees, makes any warranty, express or implied, or assumes any legal liability or responsibility for the accuracy, completeness, or usefulness of any information, apparatus, product, or process disclosed, or represents that its use would not infringe privately owned rights. Reference herein to any specific commercial product, process, or service by trade name, trademark, manufacturer, or otherwise does not necessarily constitute or imply its endorsement, recommendation, or favoring by the United States Government or any agency thereof. The views and opinions of authors expressed herein do not necessarily state or reflect those of the United States Government or any agency thereof. 
WSRC-TR-2005-00369

\title{
$M S \& T$
}

Materials Science and Technology

Keywords: Corrosion, Structural Integrity, Tank Closure

Retention - Permanent

\section{F-area Type IV Tank Liner Life Estimation}

by

\author{
B. J. Wiersma
}

SRNL SAVANNAH RIVER NATIONAL LABORATORY, AIKEN, SC 29808

Westinghouse Savannah River Company

Prepared for the U. S. Department of Energy under Contract DE-AC09-96SR18500 
Bucce f. Nurem Date: $9-27-05$ B. J. Wiersma, AUTHOR

Materials Performance \& Corrosion Technology Group MATERIALS SCIENCE AND TECHNOLOGY

Kathrim Yorohell Date:9/29/05 K. M. Marshall, TECHNICAL REVIEWER

Materials Performance \& Corrosion Technology Group MATERIALS SCIENCE AND TECHNOLOGY

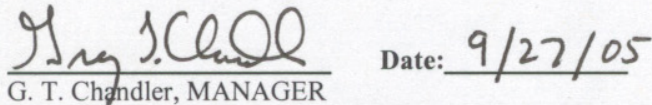
Materials Performance and Corrosion Technology Group MATERIALS SCIENCE AND TECHNOLOGY

Sicupolinim Date: 10/24/05 T. C. Robinson, Jr., MANAGER

Tank Closure Planning

PLANNING INTEGRATION AND TECHNOLOGY 


\section{F-area Type IV Tank Liner Life Estimation}

\section{Summary}

The Savannah River Site (SRS) is proceeding with closure of the Type IV waste tanks that are located in F-area. These tanks are underground concrete vaults and have been in service since the early 1960's. The interior of the concrete vault is lined with carbon steel plate. The time necessary for the carbon steel plate to disintegrate was estimated. These calculations assumed that the concrete structure was degraded and therefore the exterior of the liner is exposed to the soil conditions. Two corrosion mechanisms were examined: pitting and general corrosion. Data from soil corrosion studies performed by the National Bureau of Standards (NBS) was utilized to estimate the corrosion rate of the carbon steel liner. The following conclusions were made:

- Cecil Clay Loam in Atlanta, Georgia, a soil tested by the NBS, is representative of the SRS soil conditions near the F-Area Type IV tanks.

- The time to tank wall disintegration due to general corrosion only was estimated to be 770 years after concrete vault failure.

- The time to tank wall disintegration due to pitting corrosion was estimated to be 675 years after concrete vault failure.

- The lower bound estimate for the time to tank wall disintegration is 675 years.

\section{Introduction}

The Type IV tanks located in F-area tank farm are underground concreted vaults. The four tanks, Tanks 17 through 20, were placed in service in the early 1960's and received primarily low level waste. The concrete vault of these tanks was lined with 0.375 " thick carbon steel plate.

Two of these tanks, Tanks 17 and 20, have been closed (i.e., bulk waste removal and grouting operations completed) [1]. Heel removal operations were performed in Tanks 18 and 19 during 2000-2003. These two tanks are currently scheduled to be closed in 2007 [2]. A small residual heel of radionuclides typically remains in the tank after bulk waste removal operations are complete [3].

A performance assessment is being conducted to determine the long-term impact (e.g., 10,000 years or more) of the remaining residual heel of radionuclides on the environment. Initially the concrete vault and then the liner will provide a barrier to the leaching of radionuclides from the grout into the surrounding soil. However, over time materials eventually degrade and exposure of the grout is inevitable. This document focuses on the time necessary for the carbon steel liner to disintegrate once it is exposed to soil conditions (after concrete vault failure). Corrosion mechanisms will be a likely cause of degradation for the tank liner. A review of applicable corrosion models will be presented below. 


\section{Page 2 of 9}

\section{Background on Corrosion Models}

\section{Soil Corrosion}

Corrosion is a chemical or electrochemical reaction between a material, usually a metal, and its environment that produces a deterioration of the material and/or its properties. In the case of the F-area Type IV tanks the material is carbon steel and the environment is the soil. Corrosion occurs through the loss of metal ions at anodic areas on a structure. At the anode, the base metal is oxidized to form positively charged metal ions which combine with the negatively charged ions in the soil, with the subsequent formation of metal oxide corrosion products. At the cathode the surplus of electrons from the anode combine with positively charged hydrogen ions from the soil environment to form hydrogen and a passivating film on the metal surface.

Soil characteristics that influence the type and extent of corrosion of steel include [4]:

- aeration and permeability characteristics of the soil;

- soil acidity;

- dissolved salt content and resistivity of the soil.

Aeration and permeability are the primary attributes of soil that impact corrosion due to the fact that they control the access of oxygen and water to the steel surface. Aeration and permeability characteristics of the soil are dependent on physical characteristics such as particle size, particle size distribution, and specific gravity. Aeration also depends on the topography of the area, the depth to the water table, and the amount of rainfall.

Corrosion occurs to a lesser degree in soils that are porous, have good drainage and an ample oxygen supply (e.g., sandy soils). Clay soils which tend to have high water retention, poor aeration, and poor drainage have significantly higher corrosion rates. Corrosion by differential aeration can also result. For example if a structure or pipe passes through two soils that differ in oxygen permeability, a galvanic current flows from the poorly aerated surface (i.e., anode) to the aerated surface (i.e., cathode). Lower oxygen concentrations typically occur at the bottom of a buried steel structure where the soil is more compact and farther from the source of oxygen in the atmosphere. Thus the bottom of the buried structure is potentially more susceptible to corrosion. Oxygen concentration cells can form at random in backfilled soils due to the presence of rocks and other foreign materials. Poorly aerated soils are known to be corrosive to carbon steel and favor pit growth [5].

The acidity or alkalinity of the soil also factors into the corrosion response of a material in soil. Steel in an acidic environment $(\mathrm{pH}<4)$ tends to corrode rapidly in a general or uniform mode. In a neutral to slightly alkaline environment $(4<\mathrm{pH}<10)$ pitting corrosion tends to predominate, becoming less aggressive as the $\mathrm{pH}$ increases. In alkaline environments $(\mathrm{pH}>10)$, steel corrosion is minimal due to the stability of the passive oxide film on the metal surface. 


\section{Page 3 of 9}

The most corrosive soils are those that contain large concentrations of soluble salts (e.g., chloride). The soluble salts result in soils that have low electrical resistivities.

Resistivity measurements are readily attainable and yield measurements that trend well with corrosivity levels of the soil. Therefore, resistivity is the property most commonly used to approximate the aggressiveness of a soil. Table 1 lists the general relationship that exists between soil resistivity and the corrosion of steel in soils [6]. Backfilled soils may have a lower resistivity due to the accumulation of salts in these areas. Caution should be utilized in applying these classifications blindly, as aeration and soil acidity could also factor into the corrosive soil conditions. Additionally, resistivity measurements may vary over time due to changes in the moisture content of the soil.

Table 1. Soil Corrosivity vs. Resistivity

\begin{tabular}{|c|l|}
\hline Resistivity, ohm -centimeter & \multicolumn{1}{c|}{ Corrosiveness } \\
\hline Below 500 & Extremely Corrosive \\
\hline $500-1,000$ & Corrosive \\
\hline $1,000-2,000$ & Moderately Corrosive \\
\hline $2,000-10,000$ & Mildly corrosive \\
\hline Above 10,000 & Progressively less corrosive \\
\hline
\end{tabular}

The primary source of data for soil corrosion is a NBS investigation that was conducted in the 1930s and 40s [4]. Corrosion coupons were buried and periodically examined for general and pitting corrosion. In these studies, steels were exposed to 47 different soils for time periods up to 14 years. The soil characteristics of these soils will be compared to that of SRS soil in the vicinity of the F-area Type IV tanks. Carbon steel corrosion data for a representative soil from the database will be selected as input for the analysis.

\section{General Corrosion}

General corrosion is the term used to describe attack that proceeds in a relatively uniform manner over the entire surface of a metal or alloy. The material becomes thinner as it corrodes until its thickness is reduced to the point at which failure occurs due to the stresses on the structure. Steel in an oxidizing or acidic environment may degrade at a rate of many mils per year (mpy) [7]. However, as the $\mathrm{pH}$ of the environment increases, this rate decreases significantly. The general corrosion model assumes that the rate of wall thickness loss is independent of time. For corrosion of steels, this assumption can be conservative because the corrosion data in soil generally indicate that the corrosion rate decreases with time [4]. The time ( $\mathrm{t}_{\mathrm{f}}$, years) at which failure occurs, that is through-wall penetration occurs, is determined by the following equation:

$$
\mathrm{t}_{\mathrm{f}}=\mathrm{d} / \mathrm{g}
$$

Where $\mathrm{d}$ is the corrosion allowance (mils) (or wall thickness in the case of the liner) and $\mathrm{g}$ is the general corrosion rate (mpy). 


\section{Pitting Corrosion}

Pitting is a localized form of corrosion which occurs on passivated metallic materials exposed to aggressive environments. Pitting requires the breakdown of the passive film on the alloy and subsequent anodic dissolution of the metal at a local site while the majority of the metal surface remains intact. The pitting model assumes that a hemispherical pit forms and estimates the area breached based $\left(A_{b}, m^{2}\right)$ on the maximum pit depth $(\mathrm{h}, \mathrm{m})$, the corrosion allowance $(\mathrm{d})$, and the number of penetrating pits per container $\left(\mathrm{N}_{\mathrm{p}}, \mathrm{pits} / \mathrm{m}^{2}\right)$ [3].

$$
A_{b}=N_{p} \pi\left(h^{2}-d^{2}\right) \text { or } A_{b}=0 \text { if } h<d
$$

The typical distribution of pit sizes shows a large number of small pits with a few deep pits. The large pits represent pits that will eventually penetrate the container. The number of penetrating pits on carbon steel exposed to soil conditions has been estimated to range between 500 and 5000 per $\mathrm{m}^{2}$ [5]. For the analysis, a value of 5000 penetrating pits per $\mathrm{m}^{2}$ was assumed. This assumption represents the upper bound of the range and is therefore conservative.

The maximum pit depth, $h$, is obtained from the data generated by the NBS and takes the form [5]:

$$
\mathrm{h}=\mathrm{k} \mathrm{t}^{\mathrm{n}}(\mathrm{A} / 372)^{\mathrm{a}}
$$

where,

$\mathrm{k}=\quad$ empirical pitting parameter, $\mathrm{m} / \mathrm{yr}^{\mathrm{n}}$

$\mathrm{t}=$ corrosion time, $\mathrm{yr}$

$\mathrm{n}=$ empirical pitting exponent

$\mathrm{A}=$ representative surface area, $\mathrm{cm}^{2}$

$\mathrm{a}=$ experimentally derived empirical correlation coefficient

The term $(\mathrm{A} / 372)^{\mathrm{a}}$ corrects for the fact that pitting is a statistical process and therefore, the larger the area studied, the higher the probability of a finding a deeper pit [5]. The constant $372 \mathrm{~cm}^{2}$ is a scaling factor and represents the size of the samples in the NBS study.

\section{Inputs and Assumptions for Models}

\section{Evaluation of SRS Soil Environment}

In general the soil at SRS has been classified as a clayey sand or sandy clay that contains 20 to $40 \%$ clay [8]. To assess the potential for underground corrosion at SRS, the soil characteristics were reviewed and are summarized below:

- Moisture content from soil samples averaged from approximately $9 \%$ to approximately $38 \%[9,10]$. 


\section{Page 5 of 9}

- Soil texture over a large part of the site is described as loamy and composed of particles that are clay, silt, and sand. The texture contributes to the well drained to excessively drained soil characteristics in most areas [11].

- $\mathrm{pH}$ ranging from acidic to slightly alkaline ( $\mathrm{pH}$ of 3.6 to a high of 8 ) have been observed, but typical values are almost neutral $\mathrm{pH}[9,11]$.

- Specific conductance measurements indicate very low soluble salt levels in the soils at SRS, which is probably the result of continued leaching by percolating rain water. (Chloride and sulfate leachate levels were tested as relatively low.)

- Soil resistivity measurements taken at depths of 5 feet to 20 feet ranged from $2300 \mathrm{ohm}-\mathrm{cm}$ to $149,000 \mathrm{ohm}-\mathrm{cm}$ [11].

Soil characteristics at the SRS, which include well drained and excessively drained soils, low total dissolved solids, and neutral $\mathrm{pH}$, indicate that the potential for underground corrosion is relatively low. However, underground corrosion of piping at the SRS is well documented [12]. Soil surveys in the $\mathrm{F}$ and $\mathrm{H}$ area tank farms have indicated a generally high resistivity with pockets of lower resistance $[11,13]$. The possibility of corrosion is low in high resistivity soils, but the soil may be locally corrosive at the lower resistivities. Numerous lateral and vertical changes between sands and clays over short distances, which are typical of the coastal plain environment, were observed in the Defense Waste Processing Facility area [14]. Large variations in soil resistivity provide for a possibility of galvanic corrosion. Galvanic corrosion usually appears when the pipe traverses soils of different composition, and as a result one section of the pipe becomes anodic with respect to another.

Soil resistivity data specific to the Type IV tanks in F-area was obtained in the 1980s [11]. Table 2 shows soil resistivity data at two locations near this 4-pack of tanks as a function of depth. The resistivities are generally very high and suggest that the potential for underground corrosion is very low. There is also not a great differential in the resistivities as well. The data also fall within the observed SRS soil resistivities. The average $\mathrm{pH}$ of the well water in the $\mathrm{F}$ and $\mathrm{H}$ area is 5 [15]. This value is also typical of SRS soil conditions. The average annual rainfall the past 30 years has been approximately 49 inches [16].

A survey of the data revealed that soil conditions at the NBS test site in Atlanta, Georgia are comparable and yet conservative with respect to resistivity and $\mathrm{pH}$ when compared to SRS values (see Table 3). This soil was also used to represent the conditions surrounding the E-Area vaults [10]. Weight loss and maximum penetration data for open-hearth steel plate will be utilized to calculate the general and pitting corrosion rates, respectively. 
Table 2. Soil Resistivity Data for Area Surrounding the F-area Type IV Tanks.

\begin{tabular}{|c|c|c|}
\hline \multirow{2}{*}{ Depth (ft) } & \multicolumn{2}{|c|}{ Soil Resistivity (ohm-cm) } \\
\cline { 2 - 3 } & Southeast of Tank 19 & Northeast of Tank 17 \\
\hline 2.5 & 71,700 & 24,378 \\
\hline 5 & 68,832 & 30,592 \\
\hline 7.5 & 70,266 & 35,850 \\
\hline 10 & 51,624 & 38,240 \\
\hline 15 & 45,888 & 45,888 \\
\hline Average & 61,662 & 34,990 \\
\hline
\end{tabular}

Table 3. Representative Soil Conditions.

\begin{tabular}{|l|l|}
\hline Location & Atlanta, Georgia \\
\hline Type of Soil & Cecil Clay Loam \\
\hline Resistivity of Soil & 17,790 ohm-cm \\
\hline pH of Soil & 4.8 \\
\hline Mean Temperature & $61.2^{\circ} \mathrm{F}$ \\
\hline Annual Precipitation & 48.3 inches \\
\hline Moisture Equivalent & $33.7 \%$ \\
\hline
\end{tabular}

\section{General Corrosion}

The average corrosion rate for the open-hearth steel after 14 years was 0.43 mpy [4]. This estimate is conservative as the rate of weight loss for the buried coupons decreased with time. Thus, the corrosion rate for time periods longer than 14 years is likely lower.

\section{Pitting Corrosion}

The maximum penetration as a function of time for open hearth steel in Cecil Clay Loam was plotted [10]. A statistical curve fit yielded values for the parameters $\mathrm{k}$ and $\mathrm{n}$ of 34.49 and 0.3205 , respectively (see Equation 3).

Values for the exponent "a" in Equation 3 depend on the material and soil. Results from the literature indicate that for carbon steels "a" ranges between 0.08 and 0.32 with a mean value of 0.15 [17]. The mean value was selected for this calculation.

The choice of the area, A, has to be balanced with the assumptions of the number of penetrating pits per unit area. The area scaling factor $(\mathrm{A} / 372)$ is generally utilized to estimate the deepest pit on the surface of a structure. Therefore, use of the actual area of the structure would give an estimate of the single largest pit. The objective of these calculations is to calculate the area breached by pitting, not the largest pit, thus an estimate of the average size of a penetrating pit. Sullivan determined that given the number of penetrating pits is between 500 and $5000 \mathrm{per} \mathrm{m}^{2}$, a value for $\mathrm{A}$ of $1 \mathrm{~m}^{2}$ was appropriate [5]. Thus, the final form of Equation 3 was: 


$$
\mathrm{h}(\text { mils })=56.56 \mathrm{t}^{0.3205}
$$

\section{Results of Calculations}

\section{Determination of Wall Thickness at Time of Closure}

The initial thickness of the liner was based on the assumption that the F-area Type IV tanks will be closed in 2006. At this time the tank will have been in service for 45 years. A bounding general corrosion rate for the tank liner during its years of service was estimated to be 1 mpy [15]. The wall thickness loss prior to closure would then be 45 mils. Assuming that the steel was initially a nominal value of 0.375 inches, the wall thickness at time of closure is estimated to be 0.330 inches.

\section{General Corrosion}

The general corrosion rate in Cecil Clay Loam was estimated to be $0.43 \mathrm{mpy}$. Insertion of this rate and the wall thickness estimate above into Equation 1 indicates that the tank liner will disintegrate due to general corrosion in approximately 770 years after concrete vault failure.

\section{Pitting Corrosion}

Equation 4 was rearranged to estimate the time necessary for the first pit to penetrate through a wall 0.330 inches thick. The time for the first pit to penetrate through-wall was calculated to be 249 years after concrete vault failure. Equation 2 was then utilized to determine the time necessary for the tank liner to disintegrate due to pitting. Disintegration is defined as the time necessary for $100 \%$ of the area of the carbon steel liner to be breached. Figure 1 shows a plot of percentage of the wall breached as a function of time. From the figure it is estimated that an additional 426 years after concrete vault failure would be required to completely breach the tank liner. Thus, the total time until the liner would disintegrate due to pitting was calculated to be 675 years after concrete vault failure.

\section{Conclusions}

The time necessary for the carbon steel liner of the F-area Type IV tanks to disintegrate due to corrosion was estimated. Corrosion from the exterior of the liner due to exposure to soil conditions was considered. Two corrosion mechanisms were examined: pitting and general corrosion. Data from soil corrosion studies performed by the NBS was utilized to estimate the corrosion rate of the carbon steel liner. The following conclusions were made:

- Cecil Clay Loam, a soil tested by the NBS, is representative of the SRS soil conditions. 


\section{Page 8 of 9}

- The time to tank wall disintegration due to general corrosion only was estimated to be 770 years after concrete vault failure.

- The time to tank wall disintegration due to pitting corrosion was estimated to be 675 years after concrete vault failure.

- A lower bound estimate for the time to tank wall disintegration would be 675 years after concrete vault failure.

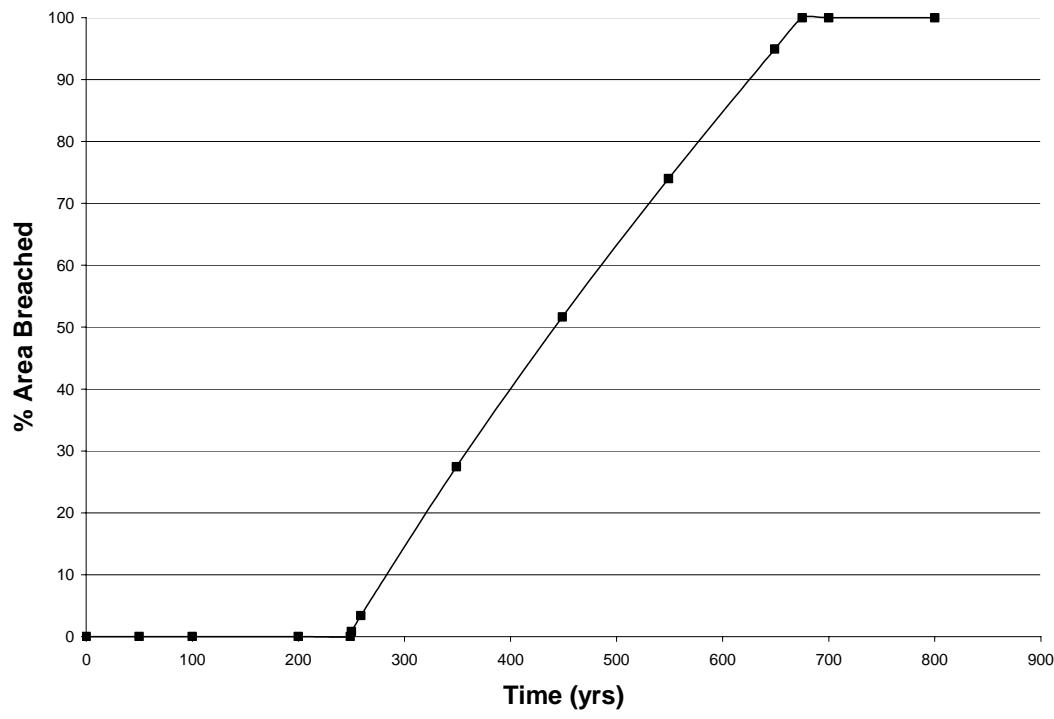

Figure 1. Percentage of the wall breached as a function of time after concrete vault failure.

\section{References}

1. T. B. Caldwell, et.al., "High Level Waste System Plan Revision 13”, HLW-200200025, April 15, 2002.

2. M. J. Mahoney and P. D. d'Entremont, "Interim Processing Plan", CBU-PIT2005-00130, June 17, 2005.

3. P. d'Entremont and J. Thomas, Characterization of Tank 19 Residual Waste, WSRC-TR-2002-00052, Revision 1, Westinghouse Savannah River Company, Aiken, South Carolina, 2002.

4. M. Romanoff, Underground Corrosion, National Bureau of Standards Circular 579, National Bureau of Standards, Washington, D. C., 1957.

5. T. M. Sullivan, Assessment of Release Rates for Radionuclides in Activated Concrete, BNL-71537-2003, August 2003.

6. Corrosion Basics: An Introduction, Published by National Association of Corrosion Engineers, Houston, Texas, 1984.

7. H. H. Uhlig, Corrosion and Corrosion Control, $2^{\text {nd }}$ Ed., John Wiley and Sons Inc., New York, 1971. 


\section{Page 9 of 9}

8. W. L. Poe, Leakage from Waste Tank 16, DP-1358, Aiken, South Carolina, November 1974.

9. Soil Survey of Savannah River Plant Area, Parts of Aiken, Barnwell, and Allendale Counties, South Carolina, a Publication of the National Cooperative Soil Survey, completed in 1987.

10. K. H. Subramanian, Corrosion Analysis for Tritium Extraction Facility Disposal in Pre-disposal Configuration, WSRC-TR-2005-00220, Westinghouse Savannah River Company, Aiken, South Carolina, May 2005.

11. Corrosion Survey Report, 200-F Separations Area At the Savannah River Plant, prepared by Ebasco, July 1982.

12. R. A. Corbett and C F. Jenkins, Soil Characteristics as Criteria for Cathodic Protection of a Nuclear Fuel Production Facility, Effects of Soil Characteristics on Corrosion, ASTM Special Technical Publication 1013, V. Chaker and J. D. Palmer, Eds., American Society of Testing and Materials, Philadelphia, Pennsylvania, 1989, pp.95-106.

13. Corrosion Investigation And Feasibility Study of Cathodic Protection For Underground Waste Storage Tanks and Process Lines in H-Area At the Savannah River Plant, prepared by Harco Corporation, July 1982.

14. D'Appolonia, Report: DWPF - Stage I Investigation Pan of Excavation and Backfill, Submitted to E.I. DuPont De Nemours and Company, Aiken, South Carolina, September 1981.

15. B. J. Wiersma, Estimation of High Level Waste (HLW) Tank Remaining Service Life, WSRC-TR-2005-00196, Westinghouse Savannah River Company, Aiken, South Carolina, May 2005.

16. SRS Atmospheric Technologies Group Database on Shrine.

17. K. H. Logan, Engineering Significance of National Bureau of Standards Soil Corrosion Data, Journal of Research of the National Bureau of Standards, Vol. 22, National Bureau of Standards, Washington, D. C., January 1939. 


\section{Distribution for WSRC-TR-2005-00369:}

S. A. Thomas, 766-H

T. C. Robinson, Jr., 766-H

J. L. Newman, 766-H

K. H. Rosenberger, 766-H

K. D. Gilbreath, 766-H

B. A. Martin, 766-H

N. C. Iyer, 773-41A

G. T. Chandler, 773-A

K. M. Marshall, 773-A

K. H. Subramanian, 773-A 